\title{
The Theological Virtues According to Bruce Springsteen
}

\author{
Andrew Gardner \\ Florida State University
}

\begin{abstract}
Bruce Springsteen's relationship to his Roman Catholic background is complex and multifaceted. This paper seeks to analyze the artist's understanding of the theological virtues of faith, hope, and love as seen in the album Wrecking Ball (2012). By juxtaposing Springsteen's understanding of these virtues with Catholicism's Thomistic tradition, scholars can see how he draws upon this tradition while creating a more robust role for the virtue of hope. This analysis of Springsteen's engagement in a theological discourse around the virtues of faith, hope, and love offers a fuller understanding of the artist's commitment to visions of the American Dream.
\end{abstract}

At a concert in Vancouver on his Wrecking Ball tour, Bruce Springsteen described "My City of Ruins" as a song "from our ghosts to your ghosts." After introducing each member of the $\mathrm{E}$ Street Band, Springsteen exclaimed: "We'd like to take a moment to feel those who are missing; those ghosts standing alongside us." As a pastor would, he guided the crowd with his hand into a moment of silence as the music stood still and the lights dimmed. ${ }^{1}$ His voice, with a sermonic tone, seemingly began to transcend the

Copyright () Andrew Gardner, 2016. I would like to thank Katharine Shaner and G. Andrew Tooze for their helpful feedback and support as I worked through this paper. I would also like to thank my mother for sharing her love of Springsteen with me many years ago. Address correspondence to abg15@my.fsu.edu.

${ }^{1}$ Magmazing Music, "Bruce Springsteen in Vancouver: My City of Ruins," December 6, 2012, accessed August 10, 2015 https://youtu.be/T4pPBGYWVNI?list=RDT4pPBGYWVNI.

BOSS: The Biannual Online-Journal of Springsteen Studies 2.1 (2016) $\underline{\text { http://boss.mcgill.ca/ }}$ 
physicality of Rogers Arena. The instruments and music, now endowed with a sort of spiritual quality, began to form a liminal space between the realm of what was thought to be physically present and the realm of what was thought to be spiritually present.

This paper analyzes the ways in which Bruce Springsteen's Wrecking Ball (2012) articulates a religious understanding of the theological virtues of faith, hope, and love as they relate to the theology of the Roman Catholic Thomistic tradition. Specifically, I argue that Springsteen's music builds upon the intellectualized medieval scholasticism of Thomas Aquinas by emphasizing the virtue of hope as a mediator between faith and love. In so doing, Springsteen appeals less to an ivory-tower medieval scholasticism and more to a working-class notion of an American Dream that is hoped for but not yet realized. Such a comparison demonstrates how a Christian and a specifically Roman Catholic imagination offers a framework for theological discourse that not only appeals to, but also functions for, individuals across various faiths, backgrounds, and nationalities.

Bruce Springsteen's childhood instilled him with a Roman Catholic imagination that offers a helpful guide to decipher the religious language and imagery found in his music. Springsteen was born in 1949 to Adele and Douglas Springsteen - a family with Irish-Italian ancestry and strong Roman Catholic faith and practice. ${ }^{2}$ He attended parochial schools for the first eight years of his education, yet, as Springsteen biographer Dave Marsh notes, parochial schools were "not the best environment for a headstrong, idealistic kid who refused to learn his place." Marsh explains that

2 Dave Marsh, Bruce Springsteen: Two Hearts: The Definitive Biography, 1972-2003 (New York: Routledge Press, 2004), 21.

BOSS: The Biannual Online-Journal of Springsteen Studies 2.1 (2016) 
Springsteen was often singled out for his misbehavior; as Springsteen later explained:

I was there eight years. That's a long time. I still remember a lot of things about it. But I don't remember anything nice about it, so I guess I didn't enjoy it. It has nothing to do with me. I'm not involved in it. I'm here to play music; I'm in a rock band. Some people pray, some people play music. ${ }^{3}$

Springsteen's experience in parochial schools left an indelible mark on his perception of the Roman Catholic Church specifically as well as religion generally. His harsh reaction against involvement in organized religion illustrates some of the ways in which religion has influenced his life. Music is what he does instead of praying instead of religion. Music is Springsteen's religion broadly construed.

Despite this less-than-positive experience with Roman Catholicism as a child, Springsteen has maintained a sense of Catholic identity, but not without a sense of humor. Wrecking Ball sparked a number of articles about the artist's spiritual life. Jim DeRogatis claimed that despite Springsteen's avowed agnosticism he finds the artist is "becoming increasingly religious as he grows older." 4 In the wake of the album's release, Springsteen jokingly admitted he was "brainwashed as a child with Catholicism.... It's like Al Pacino in the Godfather: I try to get out but they pull you back in! Once a Catholic, always a Catholic." 5 Based on these and

${ }^{3}$ Marsh, Two Hearts, 23.

4 Jim DeRogatis, "Album Review: Bruce Springsteen, 'Wrecking Ball," WBEZ 91.5, February 28, 2012 accessed April 25, 2015 http:/ / www.wbez.org/blog/jimderogatis/2012-02-28/album-review-bruce-springsteen-\%E2\% 80\% 98wreckingball\%E2\%80\%99-columbia-96817

${ }^{5}$ Neil McCormick, "Bruce Springsteen: I enjoy artists who take on the world," The Telegraph, February 16, 2012 accessed April 25, 2015

BOSS: The Biannual Online-Journal of Springsteen Studies 2.1 (2016) 
other statements, it remains possible that Springsteen feels more drawn back to Roman Catholicism than pulled. In either case, he continues to find the Catholic faith an influential force in his life.

A number of scholars have attempted to articulate the religious dimensions of Springsteen's music and lyrics. Perhaps the most comprehensive analysis is Jeffrey Symynkywicz's The Gospel According to Bruce Springsteen: Rock and Redemption, from Asbury Park to Magic. A graduate of Harvard Divinity School and a Unitarian Universalist minister, Symynkywicz addresses each album and song in chronological order, analyzing the spiritual dimensions that flow in and out Springsteen's life and music. Symynkwicz concludes his work with a list of "Bruce's Ten Commandments Suggestions for Spiritual Living":

1. The world has gone awry

2. There is a power within the souls of men and women to transcend the world, and to achieve real victories in spite of the world

3. The world is as it is

4. Life without connections is empty and dangerous

5. Our stories symbolize something deeper

6. Life is embodied

7. It's all about change

8. There is no guarantee of success

9. Hope is resilient

10. There is always something more ${ }^{6}$

Symynkwicz's work effectively analyzes the religious and spiritual dimensions of Springsteen's artistry beyond mere discussions of God. Religious and spiritual tendencies are pervasive and found in

http://www.telegraph.co.uk/culture/music/rockandpopmusic/9087360/Bru ce-Springsteen-I-enjoy-artists-who-take-on-the-world.html

${ }_{6}$ Jeffrey B. Symynkywicz, The Gospel According to Bruce Springsteen: Rock and Redemption, from Asbury Park to Magic (Louisville, KY: Westminster John Knox Press, 2008), 180-185.

BOSS: The Biannual Online-Journal of Springsteen Studies 2.1 (2016) 
all people, not simply individuals who claim a specific religious tradition. For Symynkwicz, the essence of the Gospel of Springsteen is found within an ultimate power that seeks to work within ordinary and flawed people as it strives for their wellbeing. ${ }^{7}$ From this perspective, Springsteen's religious sentiments are offered as a universal truth for all people.

Other scholars have identified key images or ideas that highlight the religious attitudes of Springsteen's music. Kate McCarthy suggests the Hebrew Scriptures' idea of the Promised Land serves as the central religious image in Springsteen's canon. McCarthy draws upon ethnographic responses to Springsteen's music as well as the increasing complexity of the image of "the Promised Land" with regards to a religious imagination that continually negotiates spaces and boundaries of the sacred. ${ }^{8}$ Jerry Gill argues that the crux of Springsteen's religious inclinations derive from the thematic image of bondage. Whether bound by time, memories, or romantic love, Gill suggests, "in the midst of all these images of bondage, Springsteen still expresses hope and affirms redemptive values." 9 From this framework, Springsteen's religious tendencies focus on a singular dimension of release from bondage.

However, both McCarthy's and Gill's analysis of Springsteen's religious tendencies fail to inspect the theology

\footnotetext{
7 Symynkywicz, The Gospel According to Bruce Springsteen, 185.

${ }^{8}$ Kate McCarthy, "Deliver Me From Nowhere: Bruce Springsteen and the Myth of the American Dream," in God in the Details: American Religion in Popular Culture, eds. Eric Michael Mazur and Kate McCarthy, (New York, NY: Routledge, 2001), 23-43.

9 Jerry Gill, "The Gospel According to Bruce," Theology Today Vol. 45 No. 1 (April 1988): 90.
}

BOSS: The Biannual Online-Journal of Springsteen Studies 2.1 (2016) 
inherent within Springsteen's music. The images of the Promised Land and of bondage only provide singular facets of the religious expression found throughout Springsteen's canon. Conversely, while Symynkywicz addresses Springsteen's music from a theological perspective, he defines Springsteen's theological enterprise quite broadly. Such a methodological framework functions within the religious sociological category H. Richard Niebuhr defines as "Christ of Culture." Within this category there is "no great tension between church and world."10 As Niebuhr explains, "This Christ of religion does not call upon men to leave homes and kindred for his sake; he enters into their homes and all of their associations as the gracious presence which adds an aura of infinite meaning to all temporal tasks" - even rock music. ${ }^{11}$ Within this Christ of Culture model, Niebuhr suggests, religion can be found in everything on the basis of Christ's expansive and universal nature.

While Symynkywicz understands the theological enterprise as one in which universal questions are addressed within a broader culture, Kathryn Tanner suggests theology may take place within culture particularly. According to Tanner, "an anthropological idea of culture encourages theologians to develop a primary interest in the particular."12 Rather than interpreting cultural phenomenon in search of its universal religious and spiritual dimensions, the theologian must analyze the particular way religion functions within the context of cultural phenomenon. From this understanding of cultural particularity, the theological enterprise

\footnotetext{
${ }^{10}$ H. Richard Niebuhr, Christ and Culture (New York: Harper, 1951), 83.

${ }^{11}$ Niebuhr, Christ and Culture, 93.

12 Kathryn Tanner, Theories of Culture: A New Agenda for Theology (Minneapolis: Fortress Press, 1997), 67.
}

BOSS: The Biannual Online-Journal of Springsteen Studies 2.1 (2016) 
is not positioned above the categories of everyday life; rather, it is positioned within them. As Tanner suggests:

As a matter of day-to-day practice, the beliefs, values, and orienting symbols of Christian life can, of course, also be directly expressed. They do not remain a merely implicit dimension of social action. Christian social practice essentially involves making theological affirmations about God and Jesus and about human life in their light. One does that, for example when one prays, confesses one's beliefs, exhorts oneself or others to properly Christian forms of behavior, preaches, or laments the injustices of life before God. 13

From Tanner's perspective, theology is not confined to explicit discussion about God, nor even a general discussion of the universal "ultimate." Instead, theology is embedded in the behaviors and thoughts that relate to a specific contextual understanding of the ultimate. Within this framework, theology is not constrained solely to the work of ivory tower intellectuals. Instead, all people participate in producing theological thought, even rock music icons like Bruce Springsteen.

Within Tanner's view of theological anthropology, the theological enterprise does not require the theologian to be cognizant of the religious ideas they are producing. Father Andrew Greely sums this idea up when he described Springsteen as engaging in "'minstrel ministry' without ever being explicit about it, or even necessarily aware of it, precisely because his imagination was shaped as Catholic."14 While anyone can produce and engage

\footnotetext{
13 Tanner, Theories of Culture, 70.

14 Fr. Andrew Greeley, "The Catholic Imagination of Bruce Springsteen," America: The National Catholic Review, February 6, 1988, accessed August 10, 2015: http://americamagazine.org/issue/100/catholic-imagination-brucespringsteen.
}

BOSS: The Biannual Online-Journal of Springsteen Studies 2.1 (2016) 
in such types of ministries and theological inquiries, the production and engagement always takes place within a specific imaginative framework, or what Jim Cullen calls an "inherited imagination" in Springsteen's case that of Roman Catholicism. ${ }^{15}$

The songs on Wrecking Ball reflect the ways in which Springsteen's Roman Catholic background inform his music and lyrics. The theological virtues of faith, hope, and love, found within the Pauline epistle to the Corinthians and addressed by medieval Roman Catholic theologian Thomas Aquinas serve as one example of this language. Aquinas not only specifically wrote about these virtues in his seminal work Summa Theologica (written 1265-1274), he also serves as one of the foremost orthodox Roman Catholic thinkers. In addition, his highly intellectualized scholasticism juxtaposes the sensory and experiential nature of Springsteen's artistic enterprise. A focus specifically on Wrecking Ball, which one reviewer described as "chock full of religious imagery," facilitates the examination of Springsteen's approach to the virtues of faith, hope, and love. ${ }^{16}$ Even so, the ideas presented on Wrecking Ball cannot be removed from the larger context of Springsteen's life and career, as other songs and albums contribute to and help shed light on the ways in which Springsteen's theological sentiments operate within this singular album. Nonetheless, incorporating the Thomistic tradition's understanding of the theological virtues into

15 Jim Cullen, Born in the U.S.A.: Bruce Springsteen and the American Tradition (Middletown, CT: Wesleyan University Press, 1997), 157.

16 Katherine Weber, “Bruce Springsteen's New Album of 'Near-Biblical Significance,' Critics Say," Christian Post, March 23, 2012, accessed August 10, 2015: http:// www.christianpost.com/news/bruce-springsteens-new-album-ofnear-biblical-significance-critics-say-71941/.

BOSS: The Biannual Online-Journal of Springsteen Studies 2.1 (2016) 
a discussion of Wrecking Ball reveals both commonality and dissimilarity within Springsteen's theological perspective.

\section{Faith}

Faith proves to be the most challenging of the three theological virtues to identify within Springsteen's canon. This elusiveness stems in part from the lack of a concrete understanding of the nature of faith. Many Christians derive definitions of faith from the Book of Hebrews which suggests "faith is the assurance of things hoped for, the conviction of things not seen" (11:1). ${ }^{17}$ Within the Roman Catholic tradition, Thomas Aquinas argues, faith precedes hope and love because "it is by faith that the intellect apprehends the object of hope and charity." 18 In essence, one cannot hope for something or love something that they do not first have faith in. For Aquinas, the theological virtues begin with faith.

Unlike Aquinas, Springsteen does not systematize the proper ordering of the virtues. Yet, for both Springsteen and Aquinas, understanding the proper "object" of faith remains crucial. Throughout Wrecking Ball, Springsteen wrestles with defining the proper object of faith. In the Roman Catholic tradition, Aquinas maintains that all three of the theological virtues must be directed towards one particular object-God. ${ }^{19}$ Springsteen's music, however, does not so narrowly define God as the sole object of faith, hope, and love. Instead, faith may be directed towards a number of objects. Much of Wrecking Ball focuses on the dangers of this theological openness by discussing the misappropriation of faith toward an undeserving object. However, as he laments this

${ }_{17}$ All biblical translations from the New Revised Standard Version (NRSV).

18 Thomas Aquinas, Summa Theologica 2.62.4; Aquinas utilizes charity as a synonym for love.

${ }^{19}$ Aquinas, Summa Theologica 2.62.1.

BOSS: The Biannual Online-Journal of Springsteen Studies 2.1 (2016) 
misplaced faith, Springsteen also affirms the existence of objects deserving of faith, most prominently the community, the self, and God.

Government serves as the most prominent example of an improper object of faith. Throughout Wrecking Ball, Springsteen roundly rejects government as an institution deserving of either confidence or devotion. The album was released in an election year following both the emergence of Occupy Wall Street as well as a prolonged congressional threat of governmental shutdown. These events highlighted America's massive wealth disparity as well as the overwhelming gridlock between President Barack Obama and the Republican-controlled Congress. According to David Fricke of Rolling Stone: "Wrecking Ball is a boldly apolitical record. The basic premise is that the true business of politics-responsible governing, a commerce of shared rewards - is broken, with plenty of guilt to go around." 20 Fricke provides valid commentary, but he may have been better suited to use the word "nonpartisan" rather than "apolitical." The album is overwhelmingly political, as numerous songs address the misappropriation of faith placed in the established elites of power, politics, and money.

From the opening song, "We Take Care of Our Own," Springsteen places his rejection of faith in the political establishment as a central theme of the album. Reminiscent of "Born in the U.S.A.," Wrecking Ball's inaugural track proclaims with measured irony: "Wherever this flag's flown / we take care of our own." While "Born in the U.S.A" presents a scathing critique of the

\footnotetext{
${ }^{20}$ David Fricke, "Wrecking Ball," Rolling Stone, March 6 2012, accessed April 12 2015, http:/ / www.rollingstone.com/music/albumreviews/wrecking-ball20120306.
}

BOSS: The Biannual Online-Journal of Springsteen Studies 2.1 (2016) 
United States' treatment of Vietnam War veterans, this song criticizes the American political and financial establishment for failing to fulfill its promise to take care of its citizens. In so doing, the song attempts to redirect America's faith towards the community and the American people rather than the politicians of the United States government. After four years under the presidency of Barack Obama, "The road of good intentions has gone dry as a bone." Recalling further failures of the George W. Bush administration, especially Hurricane Katrina in New Orleans, Springsteen remembers that for those displaced in the Superdome, “There ain't no help, the cavalry stayed home; There ain't no one hearing the bugle blowin." The phrase "We take care of our own" rings out as a protest from the local community to a government filled with "good hearts turned to stone."

Throughout the album, Springsteen makes reference to the governmental and financial establishment in a variety of ways, each of which declares that these institutions have become too consumed with power and money. "Easy Money," "Shackled and Drawn," "Jack of All Trades," and "Death to My Hometown" all make disparaging comments regarding institutional elites and portray them as Gilded Age robber barons. These predatory individuals have perpetuated a system where middle-class Americans are bound to debt and trapped in emotional and financial uncertainty. On Wrecking Ball, Springsteen argues that his faith in the operatives of this societal arrangement has expired because the institutions and individuals who have perpetuated this system are no longer deserving of the American people's faith.

Instead of simply condemning government as an improper object of faith, Springsteen offers alternative possibilities for 
redirecting faith into the suitable, deserving outlets such as the community, the self, and God. Wrecking Ball presents the sentiments of a community of people whose faith in the political and financial establishment has been depleted. Both Aquinas and Springsteen recognize that such establishments do not constitute a proper object of faith. Thomistic thought offers a redirection of that faith toward spiritual ends through faith in God. Yet, rather than rely solely on faith in the divine, Springsteen's emphasis on faith in community allows for faith to manifest itself in the physical realm.

The album trumpets the redirection of faith into communities of resistance, especially through acts of violence against the established order. For example, despite the singular pronoun in its title, "Death to My Hometown" serves as a rallying call for a community ravaged by political maneuvering that brought economic death without the use of any conventional weapons. Vengeance has become the response of the community. Their faith, whether secular or religious, in these institutions has been betrayed and the community is no longer willing to sit idly by while more wealth is accrued by the wealthy. Beyond this track, the protest raised from the beginning of the album - "We take care of our own" - weaves throughout each song. These communities of resistance and communities of care serve as a proper object of faith in order to combat the power brokers in Washington or on Wall Street. Though they may try to assuage faith toward their own ends, the "we" of Springsteen's communities proclaim that, despite the failures of others, they will continue to take care of their own.

In addition to the community, the self also serves as a proper object of faith for Springsteen. The album's title song is first and

BOSS: The Biannual Online-Journal of Springsteen Studies 2.1 (2016) 
foremost a eulogy for the old Giants Stadium. ${ }^{21}$ On the surface, "Wrecking Ball" reminisces about the arena, but underneath the lyrics recount a tale of perseverance in the face of adversity characterized in the form of a wrecking ball. Commentators on the album have cited the song's phrase, "Hold tight to your anger / And don't fall to your fears" as the album's central thesis. ${ }^{22}$ This theme functions both in order to critically question faith in the American establishment while at the same time to encourage individuals to not abandon faith entirely.

"Wrecking Ball" serves as an inspiring mantra for human resilience. The song's repeated challenge to the institutional establishment-"Bring on your wrecking ball"-becomes increasingly convincing as the song progresses. As the lyrics build to a climax, Springsteen reminds listeners that "hard times come, and hard times go." Building in intensity and emotional passion as he sings these words, Springsteen breaks through the human barrier of self-doubt and uncertainty as he shouts, "Yeah just to come again / Bring on your wrecking ball." The song welcomes the coming of difficult times with an assuring tone that positions faith in the possibility of perseverance. The singer maintains faith not

\footnotetext{
21 “50 Best Albums of 2012," Rolling Stone, December 5 2012, accessed April 12, 2015, http:/ / www.rollingstone.com/music/lists/50-best-albums-of-201220121205/bruce-springsteen-wrecking-ball-19691231.

${ }^{22}$ Neil McCormick, "Bruce Springsteen's new album Wrecking Ball: track by track review," The Telegraph, February 16 2012, accessed April 12, 2015, http://www.telegraph.co.uk/culture/music/cdreviews/9087107/BruceSpringsteens-new-album-Wrecking-Ball-track-by-track-review.html; Fiachra Gibbons, "Bruce Springsteen: 'What was done to my country was unAmerican," The Guardian, February 17 2012, accessed April 12, 2015, http:/ / www.theguardian.com/music/2012/feb/17/bruce-springsteenwrecking-ball.
}

BOSS: The Biannual Online-Journal of Springsteen Studies 2.1 (2016) 
only in his individual ability to weather any storm or hardship but also the ability of his community to do the same.

While Springsteen establishes faith in community and the self, Springsteen's Wrecking Ball, like Aquinas, also identifies a spiritual deity as a proper object of faith. Through the fusion of gospel and hip-hop on "Rocky Ground," Springsteen offers up a plea-filled prayer for guidance, and wherever prayers are present, faith in a divine hearer functions. The track begins with a chorus softly singing the refrain: "We've been traveling over rocky ground, rocky ground." Springsteen interrupts this refrain by reverently singing "Rise up shepherd, rise up. / Your flock has roamed far from the hills." Rather than a demand, his tone is more akin to a supplication. The image of the shepherd has both significance in the Prophetic literature of the Hebrew Scriptures and New Testament as it often identifies important characters that are servants of God. In addition, angels' cries of "Glory Hallelujah" remind listeners of the birth of Jesus. Both of these illustrations evoke a desire for an intimate God-Emmanuel, meaning "God with us" - to come and lead God's people.

As with most of the songs on Wrecking Ball, "Rocky Ground" does not merely identify the divine as a proper object of faith but also comments on society's misappropriation of this faith. The second verse reminds listeners: "Jesus said the money changers in this temple will not stand." Much of the song utilizes general biblical imagery, but this line references a specific story in the Gospel texts in which Jesus turns over the tables of the money exchangers in the temple in Jerusalem (Mark 11:15-19; Matthew 21:12-17; Luke 19:45-48; John 3:13-16). In the minds of many Christians, this story highlights Jesus's response to corruption 
within the religious establishment. Springsteen invokes this narrative to symbolize the political, financial, and perhaps even religious corruption in the United States, and the need for the shepherd, who could be anyone from simply a prophet to God incarnate, to gather his or her flock and bring them to highersafer-terrain.

In the middle of "Rocky Ground," a rap interlude disrupts Springsteen's gospel-like prayer. The break illustrates the difficulty of faith, suggesting that despite trying one's hardest, one's best is never good enough. These are the moments when the divine takes over and finishes the task that we cannot. Faith in God serves to take one beyond his or her individual capacities - beyond his or her "best." And while the hard times keep coming, Springsteen shows that doubt and silence are just as faithful as assurance and outspokenness. The interlude ends and the chorus swells in its repetition of the phrase "We've been traveling over rocky ground," but Springsteen's prayer has been silenced. He only intermittently sings the simple phrase, "a new day's coming." By this point, the choral refrain has become the prayer and the act of faith itself. The claim of what we have been through-the "rocky ground" becomes the very ground of faith. Rather than ending, the song fades into silence suggesting the travels continue ever faithfully over this rocky ground.

The struggle of everyday life makes the prospect of having faith difficult in and of itself, and this struggle is only exacerbated by the reality that certain institutions and ideas are not worthy objects of our faith. Both Thomas Aquinas and Springsteen remain concerned with the question of what constitutes the proper object of faith. Neither believes wealth, greed, power, Congress, Wall 
Street, or the Office of the President qualify as proper objects of faith. Whereas Aquinas suggests any faith directed to someone or something other than God is a misappropriation of faith, Springsteen suggests that, in addition to God, community and the self operate as proper objects of faith within the temporal world. Instead of solely legitimizing faith when directed toward the spiritual, Springsteen understands faith to operate on both spiritual and physical levels.

\section{Hope}

Hope is the most identifiable of the theological virtues within Springsteen's canon. As shown above, much of the scholarship focused on Springsteen and religion highlights the presence of hope illustrated through images of the Promised Land or an escape from bondage. However, this scholarship does not identify the ways in which Springsteen's understanding of hope operates in relation to faith. Deviating sharply from the Thomistic understanding, Springsteen understands hope as the virtue that sustains and carries faith through the dire straits of life.

Aquinas's intellectual framework places an overriding importance on understanding the proper order of the theological virtues. Faith precedes both hope and love within the order of the intellect. Conversely, love-also labeled charity-precedes both faith and hope in the order of perfection because "faith and hope are quickened by charity." 23 For Aquinas, hope does not have a distinct role. Hope only precedes love when what is hoped for remains unknown. If the individual knows what they hope for, "love precedes hope: for good is never hoped for unless it be [first]

\footnotetext{
${ }^{23}$ Aquinas, Summa Theologica, 2.62.4.
}

BOSS: The Biannual Online-Journal of Springsteen Studies 2.1 (2016) 
desired and loved." 24 In the ordering of the virtues, Aquinas emphasizes the role of faith and love, utilizing hope as a supplementary virtue. Faith and love inform what should be hoped for, implying that hope apart from faith and love may yield inappropriate or even dangerous desires.

This ordering of faith, hope, and love results from Aquinas's inability to properly intellectualize the virtue of hope. For Aquinas, the role of hope remains undefined. If someone believes in an object or ideal, it naturally follows that they would love that object or ideal before they hope for or desire it. Within this framework, hope remains static. The degree to which someone loves something becomes the impetus for moving toward the object or ideal that they in turn hope for. According to Springsteen, however, hope is constantly in motion. Hope carries faith toward love, sustaining faith along the journey. As he sings in "This Depression," while faith may be disrupted, hope has never expired. Faith and hope are intrinsically linked. Without hope, faith is stagnant and dead.

Jeffrey Symynkywicz provides a good illustration of Springsteen's peripatetic understanding of hope in his chapter on The Rising (2002), entitled "From Good Friday to Easter." Symynkywicz describes the album's title song as "an Easter-like anthem arising out of the darkness and despair of September 11, a national Good Friday experience if there ever was one." 25 "The Rising" takes the viewpoint of a New York City firefighter on the day of September 11 th, but, whether consciously or unconsciously, the narrator overlays this perspective with that of Christ on Easter morning from within the tomb:

\footnotetext{
${ }^{24}$ Aquinas, Summa Theologica, 2.62.4.

${ }^{25}$ Symynkywicz, The Gospel According to Springsteen, 150.
}

BOSS: The Biannual Online-Journal of Springsteen Studies 2.1 (2016) 
Can't see nothin' in front of me

Can't see nothin' coming up behind

I make my way through this darkness

I can't feel nothing but this chain that binds me

Read through the lens of Easter morning, the listener visualizes a risen Christ fumbling through the darkness. Unwrapping the burial garments that bind him, Jesus reflects on where hope is taking him as he rolls the stone away. Later on in the song, the singer bears the "cross" of his "calling" and sees "Mary in the garden" - an allusion to the Resurrection story found in the Gospel of John. Symynkywicz suggests the "li, li, li's" of the chorus might be heard as abbreviated "alleluias" bursting forth on Easter Sunday as the season of Lent completes. ${ }^{26}$ While "The Rising" serves as an anthem for a post-September $11^{\text {th }}$ New York City, the title track of Wrecking Ball resonates with similar themes of hope and the assurance of resurrection throughout life's hardships. The similarities between the themes of both songs provide one reason the Wrecking Ball tour featured "The Rising" so prominently throughout Springsteen's 2012-13 live performances. ${ }^{27}$

Hope carries both "The Rising" and "Wrecking Ball." In the midst of utter despair, doubt, and waning faith, hope moves faith from the Good Friday of September11 th to the Easter Sunday of resurrection. Such a resurrection, however, cannot be expressed monolithically. The resurrection is embodied in the hope and knowledge that hard times will come and hard times will go, yet such an embodied resurrection manifests physically in different ways for different people as they experience hardship. In any case,

\footnotetext{
26 Symynkywicz, The Gospel According to Springsteen, 150.

27 "The Rising," Brucebase, accessed August 17, 2015 :

https://brucebase.wikispaces.com/The+Rising.
}

BOSS: The Biannual Online-Journal of Springsteen Studies 2.1 (2016) 
hope remains transient and constantly moving through highs and lows of life in anticipation of resurrection at each of life's turns.

This understanding of hope arises both explicitly and implicitly throughout Wrecking Ball. In the midst of the album's dystopian landscape, hope persists. "Jack of All Trades" and "Rocky Ground" present an understanding that change, new worlds, and new days are persistently approaching. While faith may be difficult to hold on to, for Springsteen, a new reality and life is actively coming. The hope for its arrival can thus bolster waning faith in the present. Hope is therefore linked with change and movement across time and space.

Implicitly, hope takes the form of continuing the struggle of everyday life. In these situations, hope is found in actions. "Shackled and Drawn" highlights the monotony of the working man's life. Yet while the title and lyrics paint a portrait of slavery, work serves as an embodiment not of suffering but of hope. In the song, the only way the protagonist knows how to continue living in such a dystopian world is to maintain his voice through song to keep working and moving through life. Implicit hope endures through the protagonist's plea to keep trekking through life's seemingly bleak outlook.

In concert at the Hard Rock Calling Festival in 2012, Springsteen's performance evokes the centrality of hope in "Shackled and Drawn." The song begins with Springsteen leading a call and response with the audience. At the song's conclusion, Cindy Mizelle calls to the crowd saying,

I want everybody to stand up

I want everybody to stand up and be counted tonight

You know we got to pray together

Cuz it's all about love. Love.

BOSS: The Biannual Online-Journal of Springsteen Studies 2.1 (2016) 
Love is the only way. ${ }^{28}$

Mizelle utilizes a revivalist tone in her voice evoking images of a Wednesday Night Prayer Meeting. Both the call and response as well as Mizelle's fleeting sermon surround the difficult and lifedraining work featured in the song. Hope sustains the listener through the toils of a hard day's work to reach the final destination of the song epitomized by Mizelle's call: an affirmation of the need for prayer, as well as the need to be recognized and counted.

Wrecking Ball also shows hope manifest as an eschatological reality in "Land of Hopes and Dreams" - a song first performed in 1999 but officially released on the 2012 album. While some critics have criticized the song as riddled with clichés, "Land of Hopes and Dreams" nonetheless illustrates Springsteen's conception of hope as based on motion. The song depicts a train that carries people of all walks of life to the land of hopes and dreams. The lyrics describe a typical train. Two travelers have their tickets and luggage, but as the song progresses, more and more people are carried on the train. By the end of the song, Springsteen explains that the train does not even require ticket, just a willingness to climb aboard. All people have a stake in the destination of this train regardless of financial resources or past sins. In the final lines of the version released on Wrecking Ball, a chorus of voices antiphonally repeats a refrain of thankfulness to the Lord, reminding the listener that this train is carrying both a grateful and a faithful people.

It is significant that the images of hope within the music of Springsteen are transient and active. In "Land of Hopes and

\footnotetext{
${ }^{28}$ Lars Helden, "Bruce Springsteen - Shackled and Drawn - London 2012

HD," July 21, 2013, accessed August 10, 2015

https://www.youtube.com/watch?v=7wpPfvR39E8.
}

BOSS: The Biannual Online-Journal of Springsteen Studies 2.1 (2016) 
Dreams," this image is a train. Elsewhere the image of a person continuing to work through tough times or caring for neighbors or looking towards a new day serves as the image of hope. Earlier in Springsteen's career, in songs such as "Thunder Road," cars served this function. In all of these situations hope is can be found by crossing from one reality into another across space and time. Faith remains a passive reality within these circumstances. Hope serves as the active agent in sustaining and journeying with faith.

The relationship between faith and hope depicted in Springsteen's music thus rejects the Thomistic importance placed upon the ordering of the theological virtues. Aquinas focuses his attention on each virtue as a self-contained whole within a proper order. Springsteen, however, demonstrates the connectivity and relationality between the virtues. Faith and hope do not operate independently of one another nor in a pre-determined succession. Instead, Springsteen illustrates an understanding of hope that sustains and carries faith. Within this relationship between faith and hope, love becomes the currency and the perfecting characteristic of the new, hoped-for reality.

\section{Love}

For Springsteen and Aquinas, the virtue of love operates on different levels. Whereas Aquinas maintains that the virtue of love functions on a singularly theological level between an individual and God, Springsteen illustrates love functioning between individuals in relationship with one another. On Wrecking Ball, "You've Got It" serves as the album's "love song," which music critic Neil McCormick described as "light relief" from the rest of

BOSS: The Biannual Online-Journal of Springsteen Studies 2.1 (2016) 
the album's weighty themes. ${ }^{29}$ However, a look at the entirety of Wrecking Ball - as well as the rest of Springsteen's canon - reveals a conception of love as built around solidarity. For Springsteen, love is both a theological and a social virtue whose perfect embodiment marks an eschatological, hoped for reality. Hope carries one's faith towards this perfection of love.

Alternatively, according to Aquinas, love precedes hope and faith in the order of perfection. He explains: "both faith and hope are quickened by charity, and receive from charity their full complement as virtues. For thus charity is the mother and the root of all the virtues." 30 Springsteen would not necessarily agree or disagree with Aquinas on this point because Springsteen is less concerned with intellectualizing each virtue as a discrete agent within an ordered chain. Instead, within Springsteen's music, love might better be characterized as providing direction for both faith and hope. Love is more of a goal than the starting place. For example, "We Take Care of Our Own" mourns our failure to care for one another while "Jack of All Trades" elicits a hope that society will finally start following Jesus's example to begin caring for one another. For Springsteen, humanity is striving toward this fuller understanding love.

However, theological ethicist Meghan Clark explains: "As both the classic virtue theory of Aquinas and Aristotle and contemporary virtue ethics show, all virtues must have clear

\footnotetext{
${ }^{29}$ Neil McCormick, "Bruce Springsteen's new album Wrecking Ball: track by track review," The Telegraph, February 16 2012, accessed April 12 2015: http://www.telegraph.co.uk/culture/music/cdreviews/9087107/BruceSpringsteens-new-album-Wrecking-Ball-track-by-track-review.html.

${ }^{30}$ Aquinas, Summa Theologica, 2.62.4.
}

BOSS: The Biannual Online-Journal of Springsteen Studies 2.1 (2016) 
objects and ends." ${ }^{31}$ If love functions as humanity's desired end for Springsteen, the precise object of this love bears investigation. As explained above, for Aquinas, the theological virtues are clearly directed toward God. Much like his understanding of faith, Springsteen's conception of love is more capacious. Love is social, built around either companionship or romantic love, rather than a specific love of God. "This Depression," for example, showcases the need for another's love in the face of depression. The only proposed remedy for such sorrow in this song is the heart-the love-of another human being, seemingly regardless of the particular nature of that affection.

Because Springsteen's sense of love includes this social dimension, the idea of solidarity contributes to his understanding of this virtue. Clark understands solidarity to be a social virtue whose "formal object is our common humanity." 32 For Clark, solidarity strikes a balance between excessive individualism and excessive collectivism. For Springsteen, solidarity and love are collapsed into one virtue. Many Springsteen songs exhibit a balancing of these two ideas. For instance, "Shackled and Drawn" encourages listeners to "stand up and be counted" as individuals while at the same time exhorting them to take part in communal prayer.

Wrecking Ball concludes with "We Are Alive," an expression of Springsteen's eschatological vision of the perfection of love. According to McCormick, the album ends with this track providing a "campfire song for ghosts of the oppressed, martyred strikers,

\footnotetext{
31 Meghan Clark, "Anatomy of a Social Virtue: Solidarity and Corresponding Vices," in Political Theology 15 no. 1, 2014, 29-30.

${ }^{32}$ Clark, "Anatomy of a Social Virtue," 30.
}

BOSS: The Biannual Online-Journal of Springsteen Studies 2.1 (2016) 
protesters and immigrant workers, with Springsteen strumming and whistling while a Mariachi band kicks in to celebrate the eternal possibility of good triumphing over bad as an idea, if not a reality." 33 The song, however, is more particular than McCormick acknowledges. The song encompasses specific voices come from the American past: a striking railroad worker, a girl killed in the $16^{\text {th }}$ Street Baptist Church Bombing, and a migrant crossing the American border with Mexico. The voices of these deceased, however, return to their loved ones and all those living in order to proclaim that "We are alive." Death has not conquered their love for those who left their bodies to rot. Love returns at the end of each of the song's three verses through the deceased's claim that "Our souls and spirits rise / to carry the fire and light the spark / to fight shoulder to shoulder and heart to heart." 34 The listeners are provided with the image of a railroad worker next to a black girl from Birmingham next to an immigrant from Central America. Death has not quenched their ability to stand in solidarity with one another despite varying levels of oppression, identity, and privilege. In this instance, love is not only social, but love is also destructive, breaking down the barriers of class, gender, and race that separate humans - both living and dead-from one another. The song expresses an undeniable religious and spiritual understanding of love and solidarity rising above the powers of death. These religious overtones are made all the more powerful by the song's opening line: “There's a cross up yonder up on Calvary

\footnotetext{
33 Neil McCormick, "Bruce Springsteen's new album Wrecking Ball: track by track review," The Telegraph, February 16 2012, accessed April 12 2015, http://www.telegraph.co.uk/culture/music/cdreviews/9087107/BruceSpringsteens-new-album-Wrecking-Ball-track-by-track-review.html.

${ }^{34}$ McCormick, "Bruce Springsteen's new album."
}

BOSS: The Biannual Online-Journal of Springsteen Studies 2.1 (2016) 
Hill." Evoking the image of Jesus's crucifixion and resurrection, Springsteen sets the entire song up beneath the shadow of the cross.

New Testament scholar Gail O'Day has suggested Jesus's death, as recorded in the Gospel of John, serves as the "full expression of his love." 35 As the fourth Gospel transitions into chapter 13, beginning the Passover Meal and Farewell Discourse, the Gospel writer explains: "Having loved his own who were in the world, [Jesus] loved them to the end" (John 13:1). O'Day suggests readers must understand "the end" as being not only the end of Jesus's time on earth, but also signifying the fullest extent of Jesus's love - literally, extending to the end of love itself. ${ }^{36}$

The image of the cross in "We Are Alive" functions similarly as emblematic of the ultimate form of God's love and solidarity. As the embodiment and incarnation of the divine, Jesus comes to stand with humanity and die with humanity. The song, however, recognizes that death does not have the final word over love. For just as the listener hears the allusion to Jesus's death and resurrection, so too the promise of that reality for all people is realized-specifically for the marginalized and oppressed. The promise of resurrection, however, is not the end in and of itself. The purpose of resurrection serves only to further love and solidarity in hopes of this eschatological vision of deceased railroad workers, black children, and Hispanic immigrants standing together, proclaiming that their life entails a triumph over and against the powers of death.

35 Gail O'Day, "The Gospel of John," in The New Interpreter's Bible, Vol. 9, (Nashville, TN: Abington Press, 1995), 497;

36 O’Day, “John 13:1-38, The Farewell Meal," 721.

BOSS: The Biannual Online-Journal of Springsteen Studies 2.1 (2016) 


\section{Conclusion}

The analysis of faith, hope, and love highlighted in this article helps to offer a fuller understanding of Bruce Springsteen as an artist committed to visions of the American Dream. Thomas Aquinas understood the theological virtues as discrete agents operating in a logical, well-conceived order. Faith functioned first in the order of the intellect whereas love operated first in the order of perfection. Within such an arrangement, hope served to supplement the roles of faith and love. Through this rigid and cerebral understanding of the virtues, Aquinas maintained that faith, hope, and love might only be properly understood as they are directed to the divine.

Rather than perpetuating an intellectualized understanding of religion and spirituality as found within the thought of Thomas Aquinas and other medieval scholastics, Springsteen's canon creates a more integral role for hope. In so doing, Springsteen inverts the Thomistic idea that love operates first in the order of perfection. Instead, the perfection of love becomes the hoped-for goal in which there is faith operating on both a spiritual and physical level. Springsteen emphasizes the virtue of hope as that which sustains an individual's faith through times in which the perfection of love might seem unreachable.

This articulation of hope speaks to an American context that consistently looks toward the Promised Land and toward the prospect of the American Dream. For working-class Americans, such a dream often feels unreachable. Rather than relying on a systematized, Thomistic understanding of the theological virtues that privileges faith and love, Springsteen utilizes hope in order to maintain faith in the idea that a new world is, in fact, coming. For

BOSS: The Biannual Online-Journal of Springsteen Studies 2.1 (2016) 
Springsteen, hope "carries the spark" - the faith-that we may reach that eschatological reality in which love and solidarity prevail as humanity stands "shoulder to shoulder and heart to heart" in a triumph over death. Although Aquinas and Springsteen write for radically different purposes and audiences, juxtaposing these thinkers reveals that the theological enterprise is not solely an ivory-tower endeavor. With only the slightest imaginative lens, even a songwriter from New Jersey can produce a sophisticated understanding of the theological virtues that can resonate with people across faiths and nationalities.

BOSS: The Biannual Online-Journal of Springsteen Studies 2.1 (2016) 